ВИКОРИСТАННЯ МЕТОДІВ АЛЬТЕРНАТИВНОЇ КОМУНІКАЦІЇ ДЛЯ РОЗВИТКУ НАВИЧОК СПІЛКУВАННЯ В ДІТЕЙ З АУТИЗМОМ

\title{
USING ALTERNATIVE COMMUNICATION METHODS TO DEVELOP COMMUNICATION SKILLS IN CHILDREN WITH AUTISM
}

у статті подано обгрунтування проблеми використання методів альтернативної комунікації для розвитку навичок спілкування дітей з аутизмом. Здійснено теоретичний аналіз наукової літератури із цього питання, проаналізовано фрундаментальні праці Ф. Аппе, В. Башиної, К. Лебединської, О. Нікольської, Т. Скрипник, E. Tinbergen, N. Tinbergen та ін. Проаналізовано поняття «аутизм» $i$ «мовлення дітей з аутизмом». Проведено аналіз виникнення симптомів-маркерів у процесі мовлення дітей з аутизмом; розглянуто клінічний стан дітей з аутизмом, надана характеристика специфрічних особливостей мовлення таких дітей. Констатовано, що нині проблема навичок спілкування дітей 3 аутизмом є домінуючою. Розроблено й апробовано комплексну корекційно-розвивальну програму з використанням системи карток PECS для підвищення рівня комунікативних навичок дитини з аутизмом у сучасних вітчизняних умовах. Проведено експериментально-дослідну роботу із запровадженням сучасних методик: «Методики вивчення вміння вести діалог» за І. Бізіковою; анкетування для педагога для дослідження рівня комунікативних здібностей dimeй з РАС за О. Скобелєвою; опитувальник для батьків для оцінювання рівня мовленнєвого розвитку дітей за О. Ляксо. Подано детальний опис ходу та результатів дослідження. Доведено ефективність використання системи карток PECS для підвищення рівня комунікативних навичок дитини в роботі з дітьми, які страждають на аутизм. Результатом стало збагачення словникового запасу дітей, сприяння розвитку вміння вступати в діалог з однолітками. Представлено приклади есрективних мовленнєвих ігор за різними направленнями. Занотовано результати експериментальної роботи з перевірки есрективності запровадженоі програми розвитку.

Ключові слова: РДА, комунікачія, невербальний і вербальний аутизм, картки PECS, мовлення, розвиток комунікативних навичок dimeŭ з РДА.

The article substantiates the problem of using alternative communication methods to develop communication skills of children with autism. Theoretical analysis of the scientific literature on this issue, analyzed the fundamental works of F. Appe, V. Bashina, K. Lebedinskaya, O. Nikolskaya, T. Skrypnyk E. Tinbergen, $N$. Tinbergen, etc. Analyzed the concept of "autism" and "speech of children with autism". An analysis of the occurrence of symptomsmarkers of the speech process of children with autism; the clinical condition of children with autism is considered, the characteristic of specific features of speech of such children is given. It is stated that currently, the problem of communication skills of children with autism is dominant. A comprehensive correctional and development program was developed and tested using the PECS card system to increase the level of communication skills of a child with autism in modern domestic conditions. Experimental research work with the introduction of modern methods: "Methods of studying the ability to conduct a dialogue" by I. Bizikova; questionnaire for a teacher to study the level of communicative abilities of children with ASD according to O. Skobeleva; questionnaire for parents to assess the level of speech development of children by 0 . Lyakso. A detailed description of the course and the results of the experimental research are given. The effectiveness of using the PECS card system to increase the child's communication skills in working with children with autism, as a consequence of enriching their vocabulary, helping the child to develop the ability to engage in dialogue with peers. Examples of effective speech games in different areas are presented. The results of experimental work on checking the effectiveness of the implemented development program are noted.

Key words: autism, communication, nonverbal and verbal autism, PECS cards, speech, development of communication skills of children with autism.

Комунальної установи «Одеський інклюзивно-ресурсний центр № 8»

Постановка проблеми в загальному вигляді. Одним із чинників дезадаптації дітей з аутизмом $€$ порушення мовленнєвого розвитку та відсутність або спотвореність комунікативних навичок, що досить докладно відображено у фрундаментальних працях Ф. Аппе, В. Башиної, К. Лебединської, О. Нікольської, Т. Скрипник Е. Tinbergen, N. Tinbergen та ін. У дослідженнях у галузі психіатрії та психології розглянуто клінічний стан дітей 3 аутизмом, надана характеристика специфічних особливостей мовлення і спілкування таких дітей, досить докладно описані окремі методичні прийоми, спрямовані на розвиток мовлення загалом. Установлено, що в дітей з РДА порушено фрорму- вання всіх фрорм як довербального, так і вербального спілкування.

Аналіз останніх досліджень і публікацій. Т. Скрипник виділяє дві фрорми аутизму: вербальний і невербальний. У дітей, які страждають першою фрормою аутизму, наявне фрункціональне мовлення, хоча, як правило, вони починають говорити пізніше, ніж звичайні діти, і розвиток їхнього мовлення відбувається повільно й нерівномірно. Друга група дітей 3 невербальним аутизмом не набуває функціонального мовлення [6, с. 22]. Експериментальне вивчення дітей з РДА встановило, що в більшості з тих, чиє мовлення функціонально не $є$ розвиненим до семи років, здатність до спіл- 
кування й надалі пов'язана 3 вираженими труднощами. У процесі мовленнєвого розвитку в дітей іноді з'являються такі специфічні симптоми-маркери, як використання дітьми опосередкованого предмета при взаємодії з оточуючими; симптом «дельфінячого вереску»; автономне мовлення; мутизм; недиференційоване сприйняття живого й неживого; заплющування очей на початок мовлення; прагнення заплющити очі й затулити вуха руками; відвертання вбік; відмова від тілесних контактів; створення навколо себе певного простору; протест при прагненні вести їх у громадське місце [1, с. 99; 3, с. 75].

Деякі автори відмічають своєрідність у становленні експресивної сторони мовлення, яка пов'язана з помітно зниженою або повністю відсутньою реакцією на мовця. Дитина ігнорує прості, звернені до неї інструкції, натомість іноді може втручатися в незвернену до неї розмову. Часто не встановлює зоровий контакт, не використовує жести і міміку для привернення уваги, демонструє прагнення уникати контакту з оточуючими. Серед характерних патологічних форм мовлення передусім звертають на себе увагу ехолалії, своєрідна інтонація, характерні фонетичні розлади й порушення голосу 3 переважанням особливої високої тональності в кінці фррази або слова, тривале називання себе в другій або третій особі [1, с. 3; 3 , с. $64 ; 7$, с. 87$]$.

Тому досить зрозуміло, що вчені всього світу намагаються знайти клінічні або психологічні підходи, які допоможуть дитині з РДА подолати комунікативні бар'єри. Одним із інноваційних методів формування комунікативних навичок у дітей 3 аутизмом $€$ розроблена американськими дослідниками Е. Бонді та Лорі А. Фрост система спілкування 3 використанням карток PECS (The Picture Exchange Communication System) [8, c. 105].

Виділення не вирішених раніше частин загальної проблеми. Водночас проблема експериментального дослідження альтернативної комунікації щодо дітей з РДА на вітчизняному матеріалі не була об'єктом спеціального вивчення.

Тому мета статті - визначення можливості використання системи PECS для підвищення рівня комунікативних навичок дитини з аутизмом у сучасних вітчизняних умовах.

Виклад основного матеріалу. Емпіричне дослідження проводилося 3 чотирма дітьми 3 РДА, у яких спостерігається виражене порушення комунікації. На констатувальному етапі використані такі методики: «Методика вивчення умінь вести діалог» І. Бізікової; анкетування для педагога для дослідження рівня комунікативних здібностей дітей із РАС О. Скобелєвої; опитувальник для батьків для оцінювання рівня мовленнєвого розвитку дітей О. Ляксо [2, с. 64; 4 , с. $99 ; 5$, с. 114$]$.
За «Методикою вивчення умінь вести діалог» І. Бізікової з'ясовано, що загалом у дітей спостерігався низький рівень уміння вести діалог. Тільки перша дитина опинилася на середньому рівні. За результатами анкетування методикою О. Скобелєвої встановлено, що зазвичай діти не розуміли сенс пропонованих вимог у взаємодії з дорослими; не враховували думку інших дітей і не вміли доводити свою думку до оточуючих. Усі діти, які брали участь у дослідженні, не проявляли жодного інтересу до висловлювань та обговорень вчинків своїх однолітків, не намагалися поєднати свої потреби 3 інтересами однолітків. Майже всі вони зазнавали труднощів у конфліктній ситуації. Спостерігалися також проблеми з розумінням емоційного стану однолітків. Грали діти або наодинці, або в двоосібній групі, при цьому майже не використовували мовлення.

Наступна методика, опитувальник О. Ляксо, адаптована згідно 3 метою дослідження. За відповідями батьків, усі діти та чи інше контактні; знають своє ім'я, вік, ім'я психолога; на прохання дорослого спроможні повторити рухи і жести, які він демонструє; розуміють назви деяких предметів, що їх оточують; виконують прості доручення. При цьому вони не знають назви більшості дій, не розуміють слова, що зазначають розмір предметів і їх положення. Найнижчий рівень обізнаності щодо навколишнього середовища продемонструвала четверта дитина.

Для розвитку комунікативних навичок дітей з РДА нами розроблено комплексну корекційнорозвивальну програму з використанням системи PECS, спрямовану на фрормування й розвиток базових комунікативних функцій, соціоемоційних, а також діалогових навичок у дітей 3 аутизмом 6-8 років. Програма розрахована на фрормування комунікативного досвіду в парі: дитина - психолог, мати (батько) - дитина. Тривалість - 5 тижнів по 4 заняття в тиждень у вигляді індивідуальних занять, які адаптовані для кожної дитини, ураховуючи її індивідуальні особливості, потреби й інтереси. Як допоміжні засоби використовувалися ігри, іграшки, зображення, вправи, природні ситуації.

Для кожної дитини були підготовлені: 1) картки PECS із зображенням: «так», «ні», «Я», «хочу», «дай», «не хочу», «роблю», «почекай», «бачу», «ура», «допоможи»; 2) папка; 3) картонна смужка з липучкою. До початку вправ кожна дитина була ознайомлена зі стандартними картками та інструкціями до них.

Перша дитина - хлопець шість років із високо фрункціональним аутизмом. Улюблена іграшка олов'яний солдатик, гвинтокрил, лего. Улюблена дія - складати вежу, гойдатися на конячці. Тому нами підготовлені картки PECS із зображенням солдатика, ведмедика, гвинтокрила, конячки, кольорів, вежі з лего тощо. Щоразу перед почат- 
ком заняття ми віталися 3 хлопцем, називаючи його по імені, протягуючи руку для рукостискання. Хлопець добре реагував, повторював за нами: «Ласкаво просимо (ім'я педагога)». У ході проведення вправ дитина не завжди використовувала картки PECS. Хлопцю було зручно проговорювати словами прохання, або вимогу іграшки, або дії. При вправі «Так і Ні» хлопець не показував картки, якщо це була відповідь на питання про бажання (наприклад, «Ти хочеш солдатика»), але він використовував картки при питанні, що це за предмет (наприклад, «Це іграшка?»). У цьому разі дитина правильно відповідала на питання, протягуючи відповідну картку.

Згодом ця дитина почала справлятися з правою «Відмова від запропонованого предмета/ діяльності». Коли хлопцю пропонували ті предмети, які йому не подобаються, він спочатку мовчав, а після багатократного надання йому картки «не хочу» почав показувати її на всі предмети, які не хотів бачити. Ми також підсилювали значення висловлювання за допомогою інтонації невдоволення, жестів (похитування головою). Хлопець ніколи не реагував на інструкцію «почекай», тому ми використали вправу «Інструкція «Почекай». Для дитини було дуже важко навчитися слідувати цій інструкції: вона починала кричати, якщо не отримувала одразу бажаний предмет. Але після багатьох спроб за допомогою картки «почекай» хлопець, інколи й не на довгий час, почав чекати бажаний предмет чи іграшку.

Далі ми 3 дитиною вчилися давати коментарі на несподівану подію. Ми вибрали таку ситуацію: коли ми 3 дитиною сидимо, до кімнати заходить мати зі свистком, починає негучно свистіти (дитина нормально реагує на негучні звуки). Підготували додаткові картки, що відповідають ситуації: «Я» «бачу» «Мати», «свистить» (свисток). Коли заходила мати та свистіла, ми запитували: «що ти бачиш?» Тоді хлопець повинен був узяти картку «Я» «бачу» й картку із зображенням матері та свистка, розподілити їх у правильному порядку. Ми використовували підказки, щоб допомогти дитині вибрати правильні картки. Дитині не одразу, але вдалося створити речення за допомогою карток.

Вправу «Визначення власних речей» дитина виконувала одразу та без помилок. Вона коментувала кожен предмет: «мій солдатик, мій медведик, моя ручка тощо». Також дитина $з$ легкістю відповідала на запитання: «Чий ведмедик?» тощо.

Оскільки на початок дослідження хлопець не розумів значення положення предметів «близько», «далеко», «високо», «низько», ми зробили наголос на вправу «Запит інформації про місцезнаходження предмета («Де?»)». Перед початком заняття ми поклали ведмедя на шафу, олов'яного солдатика на полку (де зазвичай солдатик не зна- ходиться), лего на стіл на балконі. Коли під час заняття дитина виявила, що її улюблених іграшок немає, вона почала нервувати та кликати матір. Коли мати зайшла до кімнати (вона знала про вправу), вона допомогла поставити запитання про місцезнаходження предмету разом із дитиною: «Де ведмідь?» Коли дитина повторила питання за нею, ми показали іграшку й відповіли на питання: «Ведмідь на шафрі. Він високо» - і віддали іграшку. Вправа повторюваласяь багато разів. При цьому хлопець не міг ставити питання без допомоги, але міг відповідати на нього сам.

щоб дитина навчилася виражати емоції радості, ми використали вправу «Уміння висловити радість». Ми взяли іграшковий гвинтокрил і спитали дитину: «Хочеш запустити гвинтокрил?» Дитина мала за допомогою картки або слів дати згоду. Потім, коли іграшка злетіла, ми висловили радість за допомогою відповідних висловлювань, міміки, жестів і картки: «Ура». Коли гвинтокрил приземлився, ми продовжували виражати радість, щоб дитина мала можливість імітувати наші дії. Потім продовжили гру, але дитині ще було важко виражати емоції. Тоді ми спробували імітувати разом із дитиною емоції за допомогою міміки, жестів і коментувати їх перед дзеркалом: «Мені весело!» (посміхалися), «Мені сумно» (робили сумне обличчя), «Я плачу» (імітували плач). Дитина не повторювала, але уважно спостерігала за мімікою.

Для фрормування вміння дотримуватися правил соціальної поведінки при розмові ми використали «Правила розмови». Кожне заняття повторювали ці правила і старалися їх використовувати при кожній вправи, грі та діяльності.

Друга дитина - хлопець сім років, має діагноз атиповий аутизм. Улюблені іграшки: білий кіт, гумовий їжачок, кольорові картки. Улюблена дія: малювати олівцями, розподіляти картки за кольорами. Тому нами були підготовлені картки PECS із зображенням предметів та іграшок: білого кота, їжака, м'яча, олівців, барабанів, яблука, кольорів; картки із зображенням дій «стрибати», «кусати», «катати», «кидати»; картки, які дають дитині наочні поняття розмірів і просторових орієнтацій «великий, маленький, тонкий, товстий, високий, низький, близько, далеко». Щоразу перед початком заняття ми привітно віталися з хлопцем, називаючи його по імені, протягуючи руку для рукостискання, на що він добре реагував і повторював за нами вітання.

У ході проведення вправ друга дитина, як і перша, не завжди використовувала картки PECS. Хлопцю було зручніше проговорювати словами вимогу іграшки. При вправі «Так і Ні» хлопець не показував картки, а самостійно просив улюблену іграшку. Тоді ми спробували використати картки в ситуації, коли хлопцю подобалася іграшка, якої не 
було поряд. Демонструвалася картка із зображенням бажаного предмета й висловлювалося прохання показати їі, щоб отримати бажане. До кінця програми дитина навчилася іноді самостійно просити предмет за допомогою карток.

Оскільки дитина дуже добре справлялася 3 правою «Відмова від запропонованого предмета/діяльності» без карток і за допомогою жестів, більше уваги ми приділили відпрацюванню вправи «Інструкція «Почекай». Це було важливо, тому що хлопець зовсім не вмів чекати, йому було треба давати предмет одразу, як він бачить і бажає його. Під час вправи дитина одразу сприйняла цю інструкцію та вдало виконувала вправу. Далі ми 3 дитиною вчилися давати коментарі на несподівану подію. Якщо з першою дитиною ми використовували свисток, то з другим хлопцем ми використали таку ситуацію: під час заняття ми брали барабани й починали барабанити. Дитині одразу вдалося створити речення за допомогою карток, але хлопець допомагав собі за допомогою слів. Спочатку хлопець не розумів дії «сміятися», «стрибати», «кусати», «катати», «кидати». Тому ми акцентували увагу на виконанні саме цих дій. Для емоції радості ми використали вправу «Уміння висловити радість». Ми взяли білого іграшкового котика та спитали дитину: «Хочеш погладити свого білого котика?»

Дитина мала за допомогою картки або слів дати згоду. Вона відповіла словами. Потім, коли хлопець погладив іграшку, ми висловили радість за допомогою відповідних висловлювань, інтонацій, міміки та картки «як весело». Потім продовжили гладити котика. Дитині було важко висловлювати емоції посмішкою, але вона дуже добре показувала картку «Весело». Тоді ми спробували імітувати разом із дитиною емоції за допомогою міміки, жестів і коментували їх перед дзеркалом: «Мені весело!» (посміхались), «Мені сумно» (робили сумне обличчя), «я плачу» (імітували плач). Дитина не повторювала, але спостерігала за мімікою.

Дії «стрибати», «кусати», «катати», «кидати» ми вчили так: показували дитині одну або дві картки та виконували дію разом, проговорюючи ії: стрибали на місці, кусали яблуко, катали м'яча по підлозі та кидали його. До кінця програми дитина могла виконувати дії «коти» та «кидай» за словесною інструкцією. Також на початок дослідження дитина зовсім не розуміла розмір предметів «великий», «маленький», «тонкий», «товстий», «високий», «низький» і положення предметів «близько», «далеко», «високо», «низько». Показували предмет разом із карткою та давали йому характеристику: «М'яч - маленький, близько» або «м'яч маленький, далеко» - і разом проговорювали це. До кінця програми дитина могла охарактеризувати певні предмети: якщо ми показували м'яч, дитина відповідними картками характеризувала його: «великий», «червоний», «близько».

Для фрормування вміння дотримуватися правил соціальної поведінки при розмові ми використали стандартні «Правила розмови», які повторювали кожне заняття, і старалися їх використовувати у вправах і грі.

Третя дитина - хлопець вісім років, має діагноз атиповий аутизм 3 розумовою відсталістю. Улюблена іграшка: м'які кубики. Улюблена дія: гойдатися на гойдалці. Тому нами підготовлені картки PECS із зображенням кубиків, гойдалки, дії «гойдатися», цукерок «бджілки», прохання «допоможи». Щоразу перед початком заняття ми привітно віталися 3 хлопцем, називаючи його по імені й підіймаючи руку вверх. Спочатку хлопець добре реагував, але не повторював за нами ні дій, ні вітання. До кінця програми дитина почала теж піднімати руку, але не повторювати слова.

При вправі «Так і Ні» хлопець показував картки. Але самостійно дитина не просила улюблену іграшку ні словами, ні за допомогою карток. Тоді ми спробували використати картки так: у будь-якій ситуації, коли розуміли, що хлопець хоче іграшку, ми показували картку з їі зображенням, при цьому він отримував сам предмет. До кінця нашої програми дитина навчилася самостійно просити м'які кубики за допомогою карток: «Я» «хочу» «кубики». Щоб дитина навчилася просити повторити улюблену дію, ми використали вправу «Прохання про повторення дії», яка проходила за допомогою гойдалки. Щоб дитина навчилася просити дорослого допомогти їй, ми використовували вправу «Прохання про допомогу», у ході якої нам знадобилось підготувати додаткову картку із зображенням цукерок «бджілка». Спочатку дитині була запропонована щільно закрита банка із цукерками. Коли дитина зробила кілька невдалих спроб самостійно відкрити банку, ми простягнули руки долонями вгору так, щоб дитина передала нам коробку, i дали їй підказку: відповідну картку із символом та усною інструкцією «допоможи».

Під час вправи «Відмова від запропонованого предмета/діяльності» дитині пропонувалися барабани, до яких вона ставиться негативно. Відразу хлопець не міг висловити відмову, він починав плакати та звати матір. Коли мати заходила, вона разом із дитиною показувала картку «не хочу», підсилюючи значення висловлювання за допомогою інтонації невдоволення та жестів, і ми забирали барабани. Але до кінця програми дитина так і не навчилася самостійно відмовлятися.

Для навчання дитини реагувати на інструкцію «почекай» їй була запропонована вправа «Інструкція «Почекай». Хлопець погано справлявся із цією вправою, він нервував і не хотів ії виконувати. Необхідно було, щоб йому допомагала мати, яка тримала його руку. У силу ментальних особливос- 
тей дитини ми вирішили не виконувати вправу: «Коментарі на несподівану подію».

Вправу «Визначення належності власних речей» дитина виконувала з помилками: показуючи картку з кожним предметом, дитина називала тільки кубик. Ми спробували вивчити з дитиною займенник «мій». Кожен раз, даючи предмет і називаючи його, ми разом із дитиною проговорювали: «мій кубик», «мій олівець» та тощо. Іноді дитина повторювала й виходили двослівні речення. Хлопець не розумів значення багатьох слів: предметів, дій, ознак та емоцій. Тому були підготовлені додаткові картки: 1) такі, що позначать емоції; 2) такі, що позначать кольори та фрігури; 3) такі, що позначать посуд; 4) такі, що позначать дії. Далі ми спробували разом і дитиною імітувати емоції за допомогою міміки, жестів і коментувати їх перед дзеркалом і за допомогою карток: «Весело», «Сумно», «Плачу». Дитина не повторювала, але спостерігала за мімікою. Показуючи картку із зображенням фрігури та кольору, ми проговорювали: «Це що? Це квадрат. Квадрат якого кольору? - Квадрат чорний» тощо. Тим самим ми залучали дитину до діалогу. Коли ми показували картку та предмет, ми його називали: «Це що? - Це тарілка. 3 неї їдять» тощо. Ми показували дитині відповідну картку й виконували дію разом, проговорюючи її: стрибали на місці, катали м'яч по підлозі та кидали його. До кінця програми дитина вивчила одну фрігуру, один посуд, змогла показати чашку за допомогою картки, могла виконувати інструкції: кидати м'яч.

Для формування вміння дотримуватися правил соціальної поведінки при розмові ми також використали «Правила розмови», які повторювали кожне заняття та намагалися використовувати при кожній вправі, грі й діяльності.

Четверта дитина - хлопець вісім років, має діагноз атиповий аутизм 3 розумовою відсталістю. Улюблена іграшка - ведмедик. Улюблена дія - годувати ведмедика. Тому нами підготовлені картки PECS із зображенням ведмедика, м'яча тощо. щоразу перед початком заняття ми віталися 3 хлопцем, називаючи його по імені й підіймаючи руку вверх. Хлопець зазвичай не реагував, але через деякий час іноді піднімав руку.

Перша вправа була «Вимога предмета/ іграшки». Хлопець навчився давати картку із зображенням ведмедика, і ми ще більше ускладнили завдання: дали дитині дві картки. На одній із них був намальований ведмедик, а на другій - стіл. Дитина мала вибрати відповідну картку. Отже, хлопець навчився обирати картку бажаного предмета з двох карток. Друга вправа: «Так і Ні». До кінця програми дитина навчилася використовувати картки «Так» і «Ні» при питанні про предмети, які вона хотіла отримати. Наступною вправою було «Так» або «Ні» як підтвердження або заперечення. Наприклад, дитині показували ведмедика й питали: «Це ведмедик?» Дитина мала простягти картку «Так». Але із цією вправою дитина не змогла справитися навіть до кінця програми.

щоб дитина навчилася просити повторити улюблену дію, ми використали вправу «Прохання про повторення дії». Цю вправу ми повторювали 3 участю мами, поступово зменшуючи кількість підказок. Щоб дитина навчилася просити дорослого допомогти їй, ми використовували вправу «Прохання про допомогу». У ході вправи ми підготували додаткову картку із зображенням цукерок «скітлз». Вони ж були в банці. Цю вправу ми також виконували з участю мами. Іноді дитина давала картку.

Під час вправи «Відмова від запропонованого предмета/діяльності» дитині пропонувався м'яч, до якого дитина ставиться негативно. Хлопець відразу не міг висловити відмову, він починав плакати. Коли мати заходила, вона разом із дитиною показувала картку «не хочу», підсилюючи значення висловлювання за допомогою інтонації невдоволення та жестів, і ми забирали м'яч. Але до кінця програми дитина так і не навчилася самостійно відмовляти.

У силу ментальних особливостей дитини ми вирішили не виконувати вправи: «нструкція «Почекай»», «Коментарі на несподівану подію» та «Визначення належності власних речей». Хлопець, як і третя дитина, не розумів значення багатьох слів. Тому для фрормування розуміння значення слів (дій, ознак та емоцій) використані ті самі додаткові картки, що й для третьої дитини. Дії, які ми застосовували, були аналогічні. При роботі 3 картками, де зображені емоції, дитина не повторювала їх і не спостерігала за мімікою. Показуючи картку, ми називали фрігуру й колір, предмет. Якщо показували картку, що позначає дію, проговорювали та виконували їі разом, наприклад, стрибали на місці. До кінця програми дитина вивчила дві фрігури: чорний квадрат і червоний трикутник, один посуд: ложку, могла виконувати інструкції: стрибала разом із мамою. Для формування вміння дотримуватися правил соціальної поведінки при розмові ми використали список «Правила розмови». Повторювали кожне заняття ці правила та намагалися їх використовувати при кожній вправі, грі й діяльності.

На контрольному етапі дослідження 3 метою перевірки ефрективності використаних методів щодо формування комунікативних навичок використано ті самі діагностувальні методики, що й на констатувальному етапі.

Виявлено, що в першої дитини рівень уміння вести діалог на контрольному етапі змінився від середнього до високого; у другої та третьої дитини - 3 низького до середнього. Тобто в трьох дітей покращилися показники вмінь вести діалог. Тільки в четвертої дитини вміння вести діалог лишилося на низькому рівні. 
Досліджуючи показники комунікативних навичок дітей на констатувальному та контрольному етапах, можна побачити, що хоча їхній рівень істотно не змінився, але перша, друга і третя дитина стали краще взаємодіяти, пояснювати бажане (або небажане), просити улюблений предмет чи повторити улюблену дію за рахунок уміння користуватися картками й збільшення словникового запасу. Четверта дитина навчилася просити улюблений предмет, що також свідчить про деяке покращення комунікативних навичок.

За результатами даних, одержаних при опитуванні батьків за методикою О. Ляксо, установлено, що в першої дитини покращилися показники розуміння значення слів: вона стала розуміти значення положення предметів. Також почала використовувати двослівні речення для вираження прохання, місцезнаходження предмета, заперечення й опису ситуації. Друга дитина почала майже завжди входити в контакт. У неї покращилися показники розуміння значення слів, що позначають рослини; частини тіла людини і тварин; дії; розмір предметів і їх положення, які раніше не розуміла.

Третя дитина почала використовувати двослівні речення для вираження прохання, почала виконувати прохання та інструкції. Стала розуміти назви посуду; рослин; деяких частин тіла людини і тварини; значення певних дій; розмір предметів і їх положення, що не розуміла на початок дослідження.

Четверта дитина почала іноді звертатися за допомогою до дорослого й виконувати деякі інструкції та прохання. Також дитина почала говорити однослівні речення для вираження прохання. Почала розуміти значення певних слів і дій: меблів; посуду; домашніх тварин; фрруктів та овочів; частин тіла людини і тварин; значення деяких дій.

Висновки. Отже, установлено, що після проведеної корекційно-розвивальної програми 3 використанням системи PECS показники вміння вести діалог значно покращилися в першої, другої та третьої дитини, крім четвертого хлопця, що має діагноз атиповий аутизм із розумовою відсталістю. Але й цей хлопець навчився користуватися картками PECS, щоб обирати картку бажаного предмета з ряду карток, або при питанні про предмети, які він хотів отримати. Показники комунікативних навичок значно покращилися лише в першої дитини 3 високофункціональним аутизмом. Вона стала іноді поєднувати свої потреби в грі та заняттях 3 інтересами однолітків, почала точніше розуміти причину конорлікту й звертатися за допомогою до дорослих, а також почала іноді розуміти стан інших і проявляти співчуття до деяких людей. Також після проведення корекційно-розвивальної програми 3 використанням системи PECS фріксуються покращення мовленнєвого розвитку в усіх дітей. Найбільш значні покращення спостерігалися в четвертої дитини. Хлопець почав розуміти значення багатьох слів і дій, а також іноді самостійно звертатися за допомогою. Усе це свідчить про те, що використання системи PECS розвиває мовлення дітей, збагачує їхній словниковий запас, сприяє розвитку вміння вступати в діалог і є перспективним напрямом розвитку комунікативних навичок у дітей з аутизмом.

\section{БІБЛІОГРАФІЧНИЙ СПИСОК:}

1. Аппе Ф.К. Введение в психологическую теорию аутизма : монография. Москва : Теревинф, 2006. $216 \mathrm{c}$

2. Бизикова О.А. Развитие диалогической речи дошкольников в игре : пособие. Москва : Скрипторий, 2008. 136 с.

3. Лебединская К.С. Дети с нарушениями общения: Ранний детский аутизм : пособие. Москва : Просвещение, 1989. 95 с.

4. Скобелева О.В. Диагностика коммуникативных способностей детей дошкольного возраста. URL: https://nsportal.ru/detskiy-sad/razvitie-rechi/2012/10/27/ diagnostika-kommunikativnykh-sposobnostey-deteydoshkolnogo.

5. Скрипник Т.В. Феноменологія аутизму : монограсрія. Київ : Фенікс, 2010. 320 с.

6. Филлипова Н.В., Петелева Е.А. Исследование коммуникативных способностей и лексики у детей с ранним детским аутизмом. Теоретическая и экспериментальная психология. 2014. Т. 7. № 3. C. 72-84. 